\title{
Ki-67 expression score correlates to survival rate in gastrointestinal stromal tumors (GIST)
}

\author{
Escore de expressão de Ki-67 correlaciona-se com taxa de sobrevida em tumores estromais \\ gastrointestinais (GIST)
}

\begin{abstract}
Ricardo Artigiani NetoI, Angela Flavia Logullo", João Norberto Stávale ${ }^{\mathrm{III}}$, Laércio Gomes Lourenço ${ }^{\mathrm{IV}}$
${ }^{\mathrm{P}} \mathrm{PhD}$, Associate Professor, Department of Pathology, Investigative Pathology Division, EPM, UNIFESP, Sao Paulo-SP, Brazil. Conception and design of the study, acquisition and interpretation of data, statistical analysis, drafting the article, revising and approving the final version.

IIPhD, Associate Professor, Department of Pathology, Investigative Pathology Division, EPM, UNIFESP, Sao Paulo-SP, Brazil. Acquisition and interpretation of data, statistical analysis, drafting the article, revising and approving the final version.

IIIPhD. Associate Professor, Department of Pathology, Investigative Pathology Division, EPM, UNIFESP, Sao Paulo-SP, Brazil. Interpretation of data, revising and approving the final version.

${ }^{I V} \mathrm{PhD}$. Associate Professor, Department of Surgery, Gastroenteroly Surgery Division, EPM, UNIFESP, Sao Paulo-SP, Brazil. Interpretation of data, revising and approving the final version.
\end{abstract}

\begin{abstract}
PURPOSE: To evaluate the immunohistochemical expression of p16, Ki-67, p53 and Bcl-2 proteins in gastrointestinal stromal tumors (GIST); to assess the possible association between these variables and clinical and histopathological factors of cancer; and to check for prognostic value of these variables (survival and recurrence).

METHODS: A sample of 55 patients treated surgically for GIST in three hospitals was studied. The surgically excised tumors were confirmed as GIST by KIT, vimentin, desmin S100 protein, CD117, 1A4 and CD34 assessment in paraffin blocks.

RESULTS: Only 9 (16\%) cases of GIST were positive for p53, p16 was positive among 43.6\%; $80 \%$ of GISTs showed staining for $\mathrm{Bcl}-2$. The proliferative index (expressed as the proportion of positive cells) assessed by immunohistochemical expression of Ki-67 was high in $49 \%$ of cases. Elevated Ki-67 scores were associated to high histological grade $(\mathrm{p}=0.0026)$ and mitosis index, MI $(\mathrm{p}=0.0001)$. High Ki-67 index was associated to death. Expression of p53, p16 and Bcl-2 did not correlate to morphological or clinical variables.

CONCLUSIONS: Ki-67 immunohistochemical evaluation should be included in preoperative evaluation of GIST biopsies or surgical specimens as a prognostic tool for clinical staging; and all other proteins studied (Bcl-2, p53 and p16) did not play a role in GIST metabolic or carcinogenic process, remaining without prognostic value.
\end{abstract}

Key words: Gastrointestinal Stromal Tumors. Ki-67 Antigen. Immunohistochemistry. Survival Rate.

\section{RESUMO}

OBJETIVO: Avaliar a expressão imunoistoquímica de p16, Ki-67, p53 e Bcl-2 proteínas em tumores gastrointestinais estromais (GIST); determinar a possível associação entre essas variáveis e fatores clínicos e histopatológicos de câncer, e para verificar o valor prognóstico destas variáveis (sobrevivência e recorrência).

MÉTODOS: Uma amostra de 55 pacientes tratados cirurgicamente para GIST em três hospitais foi estudada. Os tumores extirpados cirurgicamente foram confirmados como GIST por KIT, vimentina, proteína desmina S100, CD117, 1A4 e avaliação de CD34 em blocos de parafina.

RESULTADOS: Apenas nove (16\%) casos de GIST foram positivos para p53, p16 foi positiva em 43,6\%, 80\% dos GIST apresentaram coloração para Bcl-2. O índice proliferativo (expresso como a proporção de células positivas), avaliado pela expressão imunoistoquímica de Ki-67, foi elevado em 49\% dos casos. Escores de Ki-67 elevados foram associados com alto grau histológico ( $\mathrm{p}=0,0026)$ e índice de mitose, MI ( $\mathrm{p}=0,0001)$. Alto índice de Ki-67 foi associado à morte. Expressão da p53, p16 e Bcl-2 não se correlacionou com as variáveis morfológicas ou clínicas.

CONCLUSÕES: A avaliação imunoistoquímica de Ki-67 deve ser incluída na avaliação pré-operatória de biópsias ou peças cirúrgicas de GIST como uma ferramenta prognóstica para o estadiamento clínico, e todas as outras proteínas estudadas (Bcl-2, p53 e p16) não desempenharam um papel no processo metabólico ou carcinogênico em GIST, mantendo-se sem valor prognóstico.

Descritores: Tumores do Estroma Gastrointestinal. Antígeno Ki-67. Imunoistoquímica. Taxa de sobrevida. 


\section{Introduction}

Gastrointestinal stromal tumors (GIST) are considered a rare entity, encompassing for $2.2 \%$ of gastric neoplasias, $13.9 \%$ in small intestine and only $0.1 \%$ of colon tumors. However, in the United States 3000 to 5000 new GIST cases are diagnosed yearly ${ }^{1}$. Before 1986 this entity was encompassed among gastrointestinal mesenchimal tumors. With the identification of KIT protein expression in these lesions, a novel malignant tumor referred as GIST was identified ${ }^{2,3}$.

In the 2001 consensus, immunopositivity was defined as a key element for the diagnosis of GIST, and the classification of malignancy is based on tumor size and mitotic count ${ }^{3-5}$. However, lack of uniform diagnostic criteria leaded to controversial epidemiological and survival data. Some tumors previously considered GIST could be diagnosed as other particular GI sarcomas (as leiomiosarcomas or schwannomas) ${ }^{3,6}$. Differential diagnosis among GIST and other muscular or neural tumors require therefore immunohistochemical assessment with standard profile including S100 protein, CD34, 1a4, desmin, and CD117 (c-KIT) antibody, determinant of GIST diagnosis ${ }^{3}$.

Only $5 \%$ of GISTs are sensitive to classic chemotherapy ${ }^{7}$ and radiotherapy is ineffective in this particular entity. Surgical resection was the main therapeutic approach to GIST until mesylate imatinib (Glivec), a molecular target drug that blocks KIT signalization (STI-571) ${ }^{8}$, was available for adjuvant therapy in advanced or irressecable GIST cases $^{7,9}$.

However, it is still difficult to determine which cases will metastasis or present an aggressive behavior based uniquely in morphological variables. Several potential prognostic variables were assessed in GIST, such as DNA ploidy, protein expression (S100, CD34, VEGF, S-VEGF) and genetic alterations (deletion of exon 11) without reaching statistical significance and, more important, with lack of technical reproducibility. Recently, we evaluated the role of p53 and Ki-67 immunohistochemically with preliminary favorable results ${ }^{10}$.

The objectives of this study are: 1) To evaluate the immunohistochemical expression of p16, Ki-67, p53 and Bcl-2 proteins in 55 cases of GIST; 2) to assess the possible association between these variables and clinical and histopathological factors of breast cancer; and 3) to check for prognostic value of these variables, relating them to survival and recurrence.

\section{Methods}

A total of 55 samples of surgically excised GIST, diagnosed between February of 1992 and September of 2006, were retrospectively identified from the archives of the Department of Surgical Pathology of three university Hospitals of Sao Paulo, Brazil, and were included in this study. Ethics Committees of all the three institutions approved this study.

Inclusion criteria were primary GIST tumors previously detected by immunohistochemical profile including KIT, vimentin, desmin, S100 protein, CD117, 1A4 and CD34 immunoreactivity assessment (as suggested by Fletcher et $a .^{3}$ ); paraffin blocks and clinical data available for further analysis and tumors with no preoperative chemo or radiotherapy. GIST tumors had been graded according to the standard criteria ${ }^{3}$, and to morphological categories, presence of necrosis, mitotic index (50 high power camps, hpc), tumor width and histological type and grade. These variables were morphologically assessed in hematoxylin-eosin (HE) slides by two pathologists (AFL and RAN). Clinical, survival and recurrence rates were calculated based on the follow up of all patients until October 2006.

\section{Immunohistochemical assessment}

Representative tumor paraffin-embedded tissue blocks were cut into 5 micra slides. Immunohistochemistry analysis was performed on each tumor slide block for p53, p16, Bcl2 e Ki-67, with standard streptavidin ABC methodology. Two minutes of pressure cooking at $\mathrm{pH} 6.0$ was used for antigen retrieval with p53 clone (1:x) (BioGenex Inc., San Ramon, CA, USA). Immunohistochemical essay with the tumor markers was performed using the antibodies and conditions shown in Table 1.

TABLE 1 - Immunohistochemical markers used to assess cell proliferation and apoptosis in gastrointestinal stroma tumor.

\begin{tabular}{cccccc}
\hline Antibody & Clone & Provider & Recovery & Detection & Dilution \\
\hline Bcl-2 & 124 & DAKO & Microwave & AntimouseABC & $1: 400$ \\
\hline P53 & DO-7 & DAKO & Pressure pan & Envision-mouse & $1: 2000$ \\
\hline P16 & 16 P07 & Neomarkers & Microwave & Envision-mouse & $1: 100$ \\
\hline Ki67 & MIB-1 & DAKO & Pressure pan & Envision-mouse & $1: 300$ \\
\hline
\end{tabular}

For p53, p16, and Ki-67, nuclear expression was assessed by identification of nuclear brown staining of neoplastic cells for further analysis at the nuclear markers ${ }^{11-14}$. A semiquantitative method for nuclear immunohistochemical grading was used ${ }^{15}$.

Bcl-2 showed a cytoplasmatic diffuse staining. A lesion 
was designated as positive if at least $10 \%$ of true neoplastic tumor cells expressed the antibody studied ${ }^{15-17}$. In some tumors virtually every cell expresses the marker and others may show a focal or variable percentage of positive cells.

\section{Statistical analysis}

Full clinical follow-up data, including presence of metastatic disease, were available for all GIST cases. Associations between p53, p16, Bcl-2 e Ki-67, immunoreactivity and clinic pathological parameters - including tumor size (as defined by TMN [tumor-node-metastasis] staging, $7^{\text {th }}$ edition), tumor grade (as morphological criteria) local recurrence, and distant metastasis - were evaluated by Fisher's exact test or chi-squared 2 test as appropriate. Mean age at diagnosis and positivity for $\mathrm{p} 53$, p16, Bcl2 e Ki-67 were compared using t test and Kolmogorov-Smirnov test. Survival analyses were conducted for overall survival (OS), disease-free survival (DFS), survival to metastases at specific sites, and time from first recurrence to death. DFS was defined as time to any type of recurrence, distant metastasis, or death from any cause. Survival curves were calculated using the KaplanMeier method. Tests of differences in survival between groups were performed using the log-rank test and were expressed as hazard ratios (HRs), which were estimated using Cox regression. Cox regression analysis was also used to evaluate any independent effect of prognostic factors on DFS, OS, and survival from recurrence. Factors found to be significant (at a $\mathrm{p}$ value of less than 0.05 ) in the survival analysis, together with for p53, p16, Bcl2 e Ki-67 as the factors of principal interest, were included in the regression analyses. All tests were two-tailed, and 95\% confidence intervals were presented where appropriate. All analyses were carried out using software SAS 9.1 (Statistical Analysis System, Cary, NC, USA).

\section{Results}

\section{Clinical and morphological data}

Among the 55 studied patients, 13 died from the disease $(23.6 \%)$ and 42 were alive $(76.4 \%)$ at the last follow up assessment. Among the survivors, 34 had no sign of disease $(80.9 \%)$ and 8 were currently presenting recurrence (14.5\%). All clinical epidemiological and morphological data are disposed in Table 2 .
TABLE 2 - Clinical and demographic data on gastrointestinal stromal tumor (GIST) patients.

\begin{tabular}{|c|c|c|c|}
\hline Characteristics & & $\begin{array}{l}\text { GIST } \\
(n=55)\end{array}$ & $\%$ \\
\hline \multicolumn{4}{|c|}{ Median age (range) } \\
\hline \multirow{2}{*}{ Gender } & Male & 27 & 49 \\
\hline & Female & 28 & 51 \\
\hline \multirow{2}{*}{ Age } & Median & 56 & \\
\hline & Maximum & 87 & \\
\hline \multirow{3}{*}{$\begin{array}{l}\text { Histological } \\
\text { type }\end{array}$} & Fusiform & 32 & 58 \\
\hline & Epitelioid & 15 & 27 \\
\hline & Mixed & 8 & 15 \\
\hline \multirow{5}{*}{ Site } & Stomach & 22 & 40 \\
\hline & Small bowel & 20 & 36 \\
\hline & Retroperitonium & 5 & 9 \\
\hline & Colon & 4 & 7 \\
\hline & Others & 4 & 7 \\
\hline \multirow{3}{*}{$\begin{array}{l}\text { Histological } \\
\text { grade }\end{array}$} & High & 33 & 60 \\
\hline & Moderate & 13 & 24 \\
\hline & Low & 9 & 16 \\
\hline \multirow{3}{*}{ Tumor size } & Up to $5 \mathrm{~cm}$ & 6 & 11 \\
\hline & 5 to $10 \mathrm{~cm}$ & 22 & 40 \\
\hline & More than $10 \mathrm{~cm}$ & 27 & 49 \\
\hline
\end{tabular}

The stomach was the most frequent affected organ (22 cases, or 40\%). However, atypical locations as appendix, mesenterium, rectum and pelvis were represented with one case each (disposed as "others" in Table 2). Median tumor width was $12.78 \mathrm{~cm}(0.7$ a $32 \mathrm{~cm})$ with predominance of fusiform differentiation (32 or 58.1\%).

More than $20 \%$ of the cases were composed of highgrade tumors (Table 2). Tumor necrosis was present in 31 cases (56.4\%). High mitotic index (MI) (more than 10 mitosis per high power fields) was observed in 21 GIST cases (38\%), while 8 (12\%) presented intermediary MI ( 5 to 9 mitosis per $50 \mathrm{hpf}$ ) and 
27 (49\%) only a low MI (up to 4 mitosis in $50 \mathrm{cpf}$ ).

When all morphological and clinical variables were statistically analyzed altogether, necrosis was associated to tumor width $(\mathrm{p}=0.0032)$, to $\mathrm{MI}(\mathrm{p}=0.0001)$ and also to histological grade $(p=0.0013)$. Presence of necrosis was marginally associated to evolution to death and the also to the epithelioid variant, but it did not reach statistical value ( $\mathrm{p}=0.0599$ and $\mathrm{p}=0.0562$, respectively).

Besides necrosis, MI was associated to evolution, to death $(\mathrm{p}=0.0153)$ and to the "stayed alive" $(\mathrm{p}=0.0099)$ conditions; and correlated to tumor width $(\mathrm{p}=0.0009)$ and histological grade $(\mathrm{p}=0.0001)$. Finally, histological grade was also associated to tumor width $(\mathrm{p}=0.0001)$ and evolution, since high histological grade patients' survival was significantly shorter when compared to lower-grade patients $(\mathrm{p}=0.0163)$.

\section{p53, p16, Ki-67 and Bcl-2 expression}

Preliminary diagnostic immunohistochemical profile of all tumors included analysis of desmin (seven positive cases, 12.7\%), S100 protein (17 stained cases, 30.1\%), vimentin (almost all cases stained strongly, 49 or $89.1 \%$ ), CD34 (reactivity present in 35 cases or $63.6 \%$ ), and 1A4 expression (present in 22 cases, $40 \%$ ). These data were not significantly correlated to any morphological or clinical variables.

Only nine $(16 \%)$ cases of GIST were positive for $\mathrm{p} 53$, and the proportion of neoplastic positive cells were largely variable among the positive cases.

p16, however, was positive among 25 reactive cases (43.6\%); with positivity in the majority of the transformed cells. Interestingly, more than $75 \%$ of GIST analyzed also showed staining for Bcl-2 (44 cases or $80 \%$ ).

According to the proliferative index, tumor cells were negative for $\mathrm{Ki}-67$ in 27 cases (49\%) and positive in the remaining 28.

Among the biological markers, Ki-67score reached significant correlation with other important prognostic variables. Higher Ki-67 scores were associated to high histological grade $(\mathrm{p}=0.0026$ with Fisher test, $\mathrm{p}=0.007$ with Kruskal-Wallis test) and MI $(\mathrm{p}=0.0001)$. Tumors with high Ki-67 indexes presented necrosis $(p=0.0257)$ and $p 53$ positive results $(p=0.0018)$ more frequently. Moreover, a high Ki-67 index was associated to death: 13 of $24 \mathrm{Ki}-67$-positive GIST patients died during the study and association to evolution was confirmed with Fisher and KruskalWallis tests $(\mathrm{p}=0.049$ and $\mathrm{p}=0.01$, respectively). Figure 1 shows the survival curves of positive and negative Ki-67 cases.

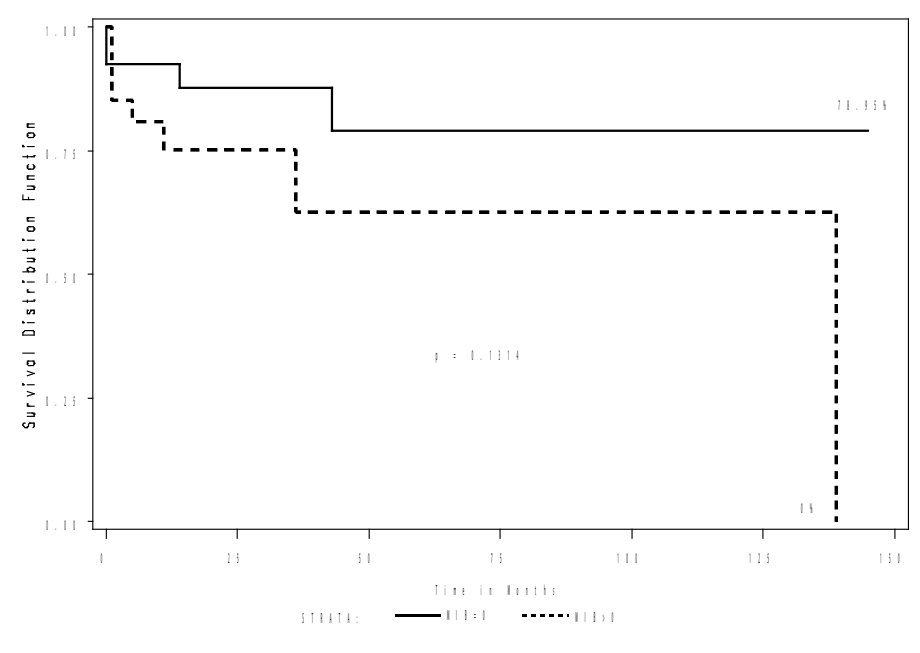

FIGURE 1 - Survival curve of patients with GIST tumors and positive or negative for Ki-67 (Mib).

Expression of p53, p16 and Bcl-2 did not show any association and did not correlate to any morphological or clinical variables (Table 3 ).

TABLE 3 - Statistical significance (p value) of the correlations between the variables.

\begin{tabular}{|c|c|c|c|c|c|c|c|c|}
\hline Variables & p16 & $\mathrm{Bcl}-2$ & Ki-67 & Degree & Mitosis & Necrosis & Size & Evolution \\
\hline p53 & 0.3402 & 1.000 & 0.0018 & 0.5614 & 0.1446 & 0.8648 & 0.8524 & 0.5617 \\
\hline $\mathrm{p} 16$ & - & 0.5698 & 0.8460 & 0.3985 & 0.8913 & 0.2433 & 0.4944 & 0.2055 \\
\hline Bcl-2 & - & - & 1.000 & 0.9302 & 0.2528 & 0.2766 & 0.5185 & 0.1454 \\
\hline $\mathrm{Ki}-67$ & - & -- & - & 0.0026 & $<0.001$ & 0.0257 & 0.0991 & 0.0161 \\
\hline $\begin{array}{l}\text { Histological } \\
\text { grade }\end{array}$ & - & - & - & - & $<0.001$ & 0.0013 & $<0.001$ & 0.1417 \\
\hline Mitosis & - & - & - & - & - & $<0.001$ & $<0.001$ & 0.0202 \\
\hline Necrosis & - & - & - & - & - & - & 0.0032 & 0.0872 \\
\hline Size & - & - & - & - & - & - & - & 0.7314 \\
\hline
\end{tabular}

\section{Discussion}

The current prognostic classification in GIST is based in tumor width and mitotic index as proposed by Fletcher et $a l .^{3}$ However, the classical mitotic index evaluation requires 50 high power camps and usually small samples are insufficient 
to complete the analysis. Moreover, there are irregularities. For instance, fixation may shrink tumor size and mitoses may "go over" during fixation ${ }^{18}$.

Recently, diagnostic approach to GIST started to include ultrasound-guided fine needle aspiration or core biopsy. Preliminary results from our group ${ }^{10}$ and also from Ando et al. ${ }^{19}$ suggested that $\mathrm{Ki}-67$ expression is a powerful prognostic tool for easy assess in smaller samples. The new Food and Drug Administration (FDA)-approved indication of imatinib mesylate in the adjuvant therapy turns biopsy specimens assessment necessary. Currently, there is no consensus in literature about the most suitable methodology for proliferation assessment and Ki-67 expression evaluation in GIST. Besides the variation of reading and assessment methodologies, limit values for positive and negative results remain controversial ${ }^{20-24}$.

We used a previously described method for Ki-67 assessment (Allred method for estrogen receptor). By using a high score for intensity ${ }^{13}$, since it is assumed that it would be equivalent in all samples and not variable, adapted this method to proliferation assessment. Distribution remained with punctuation from 0 to 5 , leading to an index from 4 to 8 . The final result is expressed in crescent categories, very reproducible. One advantage is that it constitutes an easily understandable method among distinct observers, as in ER expression, and practical for clinical application. Another important feature of this approach is that it can be performed in biopsy specimens, therefore allowing the pathologist to have an idea of proliferation status before surgery. The strong correlation to other important prognostic variables, such as histological grade $(p=0.0026)$, mitotic index $(p=0.001)$ and presence of necrosis $(\mathrm{p}=0.0257)$ endorsed the potential clinical role of this Ki-67 index. Finally, the association of Ki-67 index to evolution ( $\mathrm{p}=0.0161)$ was evidenced, demonstrating that higher $\mathrm{Ki}-67$ index is associated to poor survival rate.

The evaluation of cell cycle-related proteins in neoplasms by immunohistochemistry has been included in prognostic staging in central nervous system ${ }^{25,26}$ and other tumors ${ }^{21,27-30}$. We verified if these same proteins could also play a prognostic role in GIST ${ }^{20,31}$.

Bcl-2 protein is highly expressed in many neoplasms and also in GIST. Our results confirmed that GISTs are Bcl-2 expressing tumors. Classically, chemotherapy agents hit cells in an apoptosis pathway. In carcinomas and lymphomas, a higher contingent of apoptotic cells may represent a better response to chemotherapy ${ }^{30,32}$. Unlike many chemotherapeutic agents, imatinib mesylate, used in GIST is not based on a proliferating contingent of cells, but rather a blocking tyrosine kinase receptors and the further induction of cellular proliferation ${ }^{33}$. Therefore,
Bcl-2 would not be useful to predict response to imatinib. Indeed, most of the studies could not associate the highly expressed Bcl2 to other prognostic factors or to drug response in GIST $^{22-24,34}$. We confirmed that Bcl-2 assessment could not improve staging or prognosis assessment in GIST. The reason why Bcl-2 is so up regulated in GIST is not clear yet. One could speculate that uncontrolled proliferation in ultimately stable mesenchimal cells could trigger cell mechanisms to balance increasing population or cell transformation in GIST affects Bcl-2 gene regulation with protein stabilization and accumulation. Molecular assessment would be necessary to clarify this issue.

Gene mutations in TP53 tumor-suppressor gene are one of the most common genetic alterations in human solid tumors. Loss of p53 protein function may increase the risk for carcinogenesis $^{35,36}$. There are dozens of publications on p53 expression in GIST with a large methodological variation among them. However, the series of patients are usually smaller than ours and the results are very heterogeneous, ranging from 0 to $100 \%$ of positive neoplastic cells. In five larger studies, comprehending more than 60 patients, p53 staining was present in less than $50 \%$ of neoplastic cells and prognostic value remained controversial ${ }^{35,36}$.

We found nine p53 positive GIST cases in 55 analyzed (16\%), and p53 staining correlated to Ki-67 index, but not to any other clinical or morphological variable. The smaller contingent of p53 positive cells could mean that p53 alterations are not adamant to GIST early steps in carcinogenesis and may occur later in this process ${ }^{37,38}$. Also p53 deletion is not frequent and missense mutation seems confined to less than $50 \%$ of neoplastic cells ${ }^{39}$.

The assessment of p16 protein in GIST is still incipient and three previous studies ${ }^{40-42}$ with positivity ranging from $34 \%$ and $62 \%$ assessed p16 by PCR, RNA and tissue microarray (TMA). We found 25 immunohistochemically positive cases (45.4\%). Metilation of p16 gene was previously demonstrated by House et $a l .{ }^{42}$ with may partially explain the diversion of results.

$\mathrm{Ki}-67$ protein is one of several factors involved in cell proliferation that may be assessed easily by immunohistochemistry. $\mathrm{Ki}-67$ index reflects the proportion of cycling cells in a given population. In GIST, Ki-67 expression has been previously associated to morphological variables and also survival, but results are hardly comparable due to methodological different $\operatorname{approach}^{19,20,23,31}$.

\section{Conclusions}

The Ki-67 immunohistochemical evaluation should be included in preoperative evaluation of GIST biopsies or surgical 
specimens as a prognostic tool for clinical staging. All other proteins studied (Bcl-2, p53 and p16) did not play a role in GIST metabolic or carcinogenic process, remaining without prognostic value.

\section{References}

1. Thomas RM, Sobin LH. Gastrointestinal cancer incidence and prognosis by a histologyc type population based data 1973-1987. Cancer. 1995;75(1 Suppl):154-70.

2. Appelman HD. Smooth muscle tumors of the gastrointestinal tract. What we know now that Stout didn't know. Am J Surg Pathol. 1986;10(Suppl 1):83-99.

3. Fletcher CD, Berman JJ, Corless C, Gorstein F, Lasota J, Longley BJ, Miettinen M, O'Leary TJ, Remotti H, Rubin BP, Shmookler B, Sobin LH, Weiss SW. Diagnosis of gastrointestinal stromal tumors: A consensus approach. Hum Pathol. 2002;33(5):459-65.

4. Miettinen M, Sobin LH, Lasota J. Gastrointestinal stromal tumors of the stomach: a clinicopathologic, immunohistochemical, and molecular genetic study of 1765 cases with long-term follow-up. Am J Surg Pathol. 2005;29(1):52-68.

5. Appelman HD. Smooth muscle tumors of the gastrointestinal tract. What we know now that Stout didn't know. Am J Surg Pathol. 1986;10(Suppl 1):83-99.

6. Kindblom LG, Remotti HE, Aldenborg F, Meis-Kindblom JM. Gastrointestinal pacemaker cell tumor (GIPACT): gastrointestinal stromal tumors show phenotypic characteristics of the interstitial cells of Cajal. Am J Pathol. 1998;152(5):1259-69.

7. Dematteo RP, Heinrich MC, El-Rifai WM, Demetri G. Clinical management of gastrointestinal stromal tumors: before and after STI-571. Hum Pathol. 2002;33(5):466-77.

8. Joensuu H, Roberts PJ, Sarlomo-Rikala M, Andersson LC, Tervahartiala P, Tuveson D, Silberman S, Capdeville R, Dimitrijevic S, Druker B, Demetri GD. Effect of the tyrosine kinase inhibitor STI571 in a patient with a metastatic gastrointestinal stromal tumor. N Engl J Med. 2001;344(14):1052-6.

9. Reichardt P. Optimising therapy for GIST patients. EJC Supplements. 2006;4(Suppl 1):19-26.

10. Neves LRO, Oshima CTF, Artigiani-Neto R, Yanaguibashi G, Lourenco LG. Ki67 and p53 em tumores estromais gastrointestinais - GIST [Ki67 and p53 in gastrointestinal stromal tumors - GIST]. Arq Gastroenterol. 2009;46(2):116-20.

11. Buza N, Tavassoli FA. Comparative analysis of P16 and P53 expression in uterine malignant mixed mullerian tumors. Int $\mathrm{J}$ Gynecol Pathol. 2009;28(6):514-21.

12. Jeschke U, Schiessl B, Mylonas I, Kunze S, Kuhn C, Schulze S, Friese K, Mayr D. Expression of the proliferation marker Ki-67 and of p53 tumor protein in trophoblastic tissue of preeclamptic, HELLP, and intrauterine growth-restricted pregnancies. Int J Gynecol Pathol. 2006;25(4):354-60.

13. Lopes JM, Nesland JM, Reis-Filho JS, Holm R. Differential Ki67 and bcl-2 immunoexpression in solid-glandular and spindle cell components of biphasic synovial sarcoma: a double immunostaining assessment with cytokeratin and vimentin. Histopathology. 2002;40(5):464-71.

14. Choong PF, Akerman M, Willén H, Andersson C, Gustafson P, Baldetorp B, Fernö M, Alvegard T, Rydholm A. Prognostic value of Ki-67 expression in 182 soft tissue sarcomas. Proliferation--a marker of metastasis? APMIS. 1994;102(12):915-24.

15. Allred DC, Harvey JM, Berardo M, Clark GM. Prognostic and predictive factors in breast cancer by immunohistochemical analysis. Mod Pathol. 1998;11(2):155-68.

16. Allred DC, Bryant J, Land S, Paik S, Fisher E, Julian T, Fisher B. Estrogen receptor expression as a predictive marker of the effectiveness of tamoxifen in the treatment of DCIS: Findings from NSABP Protocol B-24. Breast Cancer Res Treat. 2002;76(1):S36 (abstr \#30).

17. Harvey JM, Clark GM, Osborne CK, Allred DC. Estrogen receptor status by immunohistochemistry is superior to the ligand-binding assay for predicting response to adjuvant endocrine therapy in breast cancer. J Clin Oncol. 1999;17(5):1474-81.

18. Reichardt P, Hogendoorn PC, Tamborini E, Loda M, Gronchi A, Poveda A, Schöffski P. Gastrointestinal stromal tumors I: pathology, pathobiology, primary therapy, and surgical issues. Semin Oncol. 2009;36(4):290-301.

19. Ando N, Goto H, Niwa Y, Hirooka Y, Ohmiya N, Nagasaka T, Hayakawa T. The diagnosis of GI stromal tumors with EUSguided fine needle aspiration with immunohistochemical analysis. Gastrointest Endosc. 2002;55(1):37-43.

20. Nakamura N, Yamamoto H, Yao T, Oda Y, Nishiyama K, Imamura M, Yamada T, Nawate H, Tsuneyoshi M. Prognostic significance of expressions of cell-cycle regulatory proteins in gastrointestinal stromal tumor and the relevance of the risk grade. Hum Pathol. 2005;36(7):828-37.

21. Pindzola JA, Palazzo JP, Kovatich AJ, Tuma B, Nobel M. Expression of p21WAF1/CIP1 in soft tissue sarcomas: a comparative immunohistochemical study with p53 and Ki-67. Pathol Res Pract. 1998;194(10):685-91.

22. Noguchi T, Sato T, Takeno S, Uchida Y, Kashima K, Yokoyama S, Müller W. Biological analysis of gastrointestinal stromal tumors. Oncol Rep. 2002;9(6):1277-82.

23. Abdulkader I, Cameselle-Teijeiro J, Gude F, Fraga M, VarelaDurán J, Barreto F, Forteza J. Predictors of malignant behaviour in gastrointestinal stromal tumours: a clinicopathological study of 34 cases. Eur J Surg. 2002;168(5):288-96.

24. Wong NA, Young R, Malcomson RD, Nayar AG, Jamieson LA, Save VE, Carey FA, Brewster DH, Han C, Al-Nafussi A. Prognostic indicators for gastrointestinal stromal tumours: a clinicopathological and immunohistochemical study of 108 resected cases of the stomach. Histopathology. 2003;43(2):118-26.

25. Brown DC, Gatter KC. Monoclonal antibody Ki-67: its use in histopathology. Histopathology. 1990;17(6):489-503.

26. Brown DC, Gatter KC. Ki67 protein: the immaculate deception? Histopathology. 2002;40(1):2-11

27. Logullo AF, Lopes AB, Nonogaki S, Soares FA, Netto MM, Nishimoto IN, Brentani MM. C-erbB-2 expression is a better predictor for survival than galectin-3 or p53 in early-stage breast cancer. Oncol Rep. 2007;18(1):121-6.

28. Logullo AF, Kowalski LP, Nonogaki S, Miguel RE, Torloni H, Brentani RR. P53 overexpression in epidermoid carcinoma of the head and neck. Sao Paulo Med J. 1997;115(1):1349-55.

29. Jesus EC, Matos D, Artigiani R, Waitzberg AF, Goldenberg A, Saad SS. Assessment of staging, prognosis and mortality of colorectal cancer by tumor markers: receptor erbB-2 and cadherins. Acta Cir Bras. 2005;20(6):422-7.

30. Lustosa SA, Logullo A, Artigiani R, Saad SS, Goldenberg A, Matos D. Analysis of the correlation between p53 and bcl-2 expression with staging and prognosis of the colorectal adenocarcinoma. Acta Cir Bras. 2005;20(5):353-7.

31. Yamamoto H, Oda Y, Kawaguchi K, Nakamura N, Takahira T, Tamiya S, Saito T, Oshiro Y, Ohta M, Yao T, Tsuneyoshi M. c-kit and PDGFRA mutations in extragastrointestinal stromal tumor (gastrointestinal stromal tumor of the soft tissue). Am J Surg Pathol. 2004;28(4):479-88. 
32. Kondo E, Yoshino T. Expression of apoptosis regulators in germinal centers and germinal center-derived B-cell lymphomas: Insight into B-cell lymphomagenesis. Pathol Int. 2007;57(7):391-7.

33. Siehl J, Thiel E. C-kit, GIST, and imatinib. Recent Results Cancer Res. 2007;176:145-51.

34. Kontogianni K, Demonakou M, Kavantzas N, Lazaris Ach, Lariou K, Vourlakou C, Davaris P. Prognostic predictors of gastrointestinal stromal tumors: a multi-institutional analysis of 102 patients with definition of a prognostic index. Eur J Surg Oncol. 2003;29(6):54856.

35. Lane DP. p53 and human cancers. Br Med Bull. 1994;50(3):582-99.

36. Levine AJ. p53 the cellular gatekeeper for growth and division. Cell. 1997;88(3):323-31.

37. Martínez-Consuegra N, Baquera-Heredia J, de León-Bojorge B, Padilla-Rodríguez A, Hidalgo CO. Expression of p53 and BCI-2 as prognostic markers and for anatomical location in gastrointestinal stromal tumors (GIST). Clinico-pathological and immunohistochemistry study of 19 cases. Rev Gastroenterol Mex. 2006;71(3):269-78.

38. Sakurai S, Fukayama M, Kaizaki Y, Saito K, Kanazawa K, Kitamura M, Iwasaki Y, Hishima T, Hayashi Y, Koike M. Telomerase activity in gastrointestinal stromal tumors. Cancer. 1998;83(10):2060-6.

39. Michalany J. Técnica histológica em anatomia patológica: com instruções para o cirurgião, enfermeira e citotécnico. São Paulo: Epu; 1981.

40. Ricci R, Arena V, Castri F, Martini M, Maggiano N, Murazio M, Pacelli F, Potenza AE, Vecchio FM, Larocca LM. Role of p16/ INK4a in gastrointestinal stromal tumor progression. Am J Clin Pathol. 2004;122(1):35-43.

41. Haller F, Gunawan B, von Heydebreck A, Schwagner S, Schulten HJ, Wolf-Salgó J, Langer C, Ramadori G, Sültmann H, Füzesi L. Prognostic role of E2F1 and members of the CDKN2A network in gastrointestinal stromal tumors. Clin Cancer Res. 2005;11(18):658997.

42. House MG, Guo M, Efron DT, Lilemoe KD, Cameron JL, Syphard JE, Hooker CM, Abraham SC, Montgomery EA, Herman JG, Brock MV. Tumor suppressor gene hypermethylation as a predictor of gastric stromal tumor behavior. J Gastrointest Surg. 2003;7(8):100414.

\section{Correspondence:}

Ricardo Artigiani Neto

Universidade Federal de São Paulo (UNIFESP)

Escola Paulista de Medicina-EPM

Departamento de Patologia

Rua Botucatu, 740/1ํandar

04023-062 São Paulo - SP Brasil

Tel.: (55 11)9561-5449

ricardoartigiani@hotmail.com

Received: December 14, 2011

Review: February 15, 2012

Accepted: March 12, 2012

Conflict of interest: none

Financial source: none

${ }^{1}$ Research performed at the Department of Pathology, Investigative Pathology Division, Paulista School of Medicine (EPM), Federal University of Sao Paulo (UNIFESP), Brazil. Part of PhD degree thesis.

Tutor: João Norberto Stávale. 